\title{
Seasonal Epidemic of Swine Flu: Role of Hospital Administration in Preparedness
}

\author{
Ravi Gupta ${ }^{1}$, Sonali Shamdasani ${ }^{2}$, Aditi Mehra ${ }^{3}$
}

\begin{abstract}
Aim: To analyze the trend of swine flu disease and the demographic details of the category C swine flu patients admitted in a tertiary care hospital and assess their outcome. Based on this, we want to define the role of hospital administrators in planning for management of swine flu epidemic. Materials and methods: Record based retrospective analysis of confirmed cases of swine flu infection from January, 2016 to February, 2019 was done. The trend of disease during the study period and the demographic details of the confirmed cases in category $C$ were assessed to analyze the variables that could affect the outcome of the disease.

Results: Among 466 suspected cases, $29.4 \%(n=137)$ were positive for swine flu infection. The trend of the disease over the study period was variable. A total of 118 patients (86.1\%) were of category C. Amongst category C, maximum cases and mortalities were in age-group 21-60 years $(p<0.001)$. The occurrence and mortality of disease $(p=0.098, p=0.249$ respectively) was almost equal among both genders. Around $43.2 \%$ category $C$ patients required mechanical ventilation and $56.8 \%$ required oxygen therapy. The mortality was very high amongst category $C$ patients on mechanical ventilation (94.1\%). No association was observed between comorbidity and mortality.

Conclusion: By knowing the trend of disease and the outcome, planning can be done to effectively manage swine flu epidemic in terms of infrastructure, manpower and other resources. Thus, the hospital administrators play pivotal role.

Clinical significance: The study will help the hospital administrators to understand the variable trend of disease and demographic profile planning for management of swine flu epidemic.

Keywords: Comorbidity, Demographic profile, Hospital administration, Mechanical ventilation, Outcome, Swine flu.

Journal of Postgraduate Medicine Education and Research (2019): 10.5005/jp-journals-10028-1333
\end{abstract}

\section{INTRODUCTION}

Swine influenza, also called swine flu, hog flu or pig flu, is an infection caused by one of the several types of swine influenza viruses (SIV) ${ }^{1}$ which are common throughout the pig population in the world. The classical swine flu virus, an influenza type A (H1N1) virus was first isolated from a pig in $1930 .^{2}$

Although, the swine flu virus rarely affected humans in the past as a "variant virus" but now it has emerged as a common infection. Influenza viruses are now leading to annual epidemics and occasional pandemics that have claimed the lives of millions. Although the clinical symptoms of infection with the swine flu virus do not differ from those of seasonal influenza, the mortality and morbidity in the case of former is much higher. ${ }^{3}$ Thus, there is a continued need for subtyping and laboratory confirmation in any case of influenza. With the reporting of first case of human infection in Mexico in March, 2009, there was an outbreak of the disease worldwide which affected more than 94,000 cases in around 100 countries within 3-4 months. ${ }^{4}$ Swine influenza is seen predominantly in the mid-western United States, Mexico, Canada, South America, Europe (including UK, Sweden, and Italy), Kenya, Mainland China, Taiwan, Japan, and India.

As per the data of National Centre for Disease Control (NCDC), New Delhi, India, there were 70,392 confirmed cases of swine flu from January, 2016 to February, 2019, of which 4,086 patients lost their lives (Table 1). ${ }^{5}$

Thus, from the year 2016, the trend of prevalence of infection is not uniform with sudden spurt in number of cases in the year, 2017 and a significant decline in the year, 2018. At the time of writing of the paper in 2019, 14,803 number of cases have already been confirmed in India which has shown a second spurt of the disease.

\footnotetext{
${ }^{1-3}$ Department of Hospital Administration, Government Medical College and Hospital, Chandigarh, India
}

Corresponding Author: Sonali Shamdasani, Department of Hospital Administration, Government Medical College and Hospital, Chandigarh, India, Phone: +91 9781581692, e-mail: sonali7872@ gmail.com

How to cite this article: Gupta R, Shamdasani S, Mehra A. Seasonal Epidemic of Swine Flu: Role of Hospital Administration in Preparedness. J Postgrad Med Edu Res 2019; 53(4):147-151.

Source of support: Nil

Conflict of interest: None

Although the antiviral drug (Oseltamivir) and vaccine are available but the influenza strain changes so frequently that it is not a foolproof treatment. So, the supportive measures remain the mainstay treatment. Due to high mortality of patients, the word "Swine flu" has become a kind of phobia for both healthcare workers and general public.

Table 1: Year-wise cases of swine flu infection in India ${ }^{5}$

\begin{tabular}{lcc}
\hline Year & $\begin{array}{l}\text { Confirmed } \\
\text { swine flu cases }\end{array}$ & $\begin{array}{l}\text { Mortality due } \\
\text { to swine flu }\end{array}$ \\
\hline 2016 & 1,786 & 265 \\
2017 & 38,811 & 2,270 \\
2018 & 14,992 & 1,103 \\
2019 (till 24th Feb, 2019) & 14,803 & 448 \\
Total & 70,392 & 4,086 \\
\hline
\end{tabular}

(0) The Author(s). 2019 Open Access This article is distributed under the terms of the Creative Commons Attribution 4.0 International License (https://creativecommons. org/licenses/by-nc/4.0/), which permits unrestricted use, distribution, and non-commercial reproduction in any medium, provided you give appropriate credit to the original author(s) and the source, provide a link to the Creative Commons license, and indicate if changes were made. The Creative Commons Public Domain Dedication waiver (http://creativecommons.org/publicdomain/zero/1.0/) applies to the data made available in this article, unless otherwise stated. 
As the trend of disease is not uniform and mortality is high, the hospitals should be prepared to manage epidemics. By knowing the trend of the disease and demographic profile of swine flu patients, the hospital administrators can plan for requirements in terms of robust infrastructure, availability and timely supply of material and manpower.

As of now, there is no study which has reported the role of hospital administration in managing the swine flu by knowing the demographic trends in the causation of disease as well as mortality resulting from the disease. Thus, the present study is designed to analyze the trend of disease and demographic details of category $C$ swine flu patients admitted in a tertiary care hospital from January, 2016 to February, 2019 and assess the outcome which will be used to further strengthen the patient care.

\section{Materials and Methods}

This study is a retrospective record based analysis of suspected and confirmed cases of swine flu infection who attended the emergency department from January, 2016 to February, 2019.

Case definitions followed were: (i) suspected case defined as a case with signs and symptoms as per categories $A, B$ and $C^{6}$ (Table 2); and (ii) confirmed case defined as a suspected case that was positive by real time reverse transcription polymerase chain reaction (RT-PCR).

In this study, the trend of the confirmed cases was analyzed over the study period. Further, the demographic details of the

Table 2: Categorization of seasonal influenza cases_-guidelines issued by Ministry of Health and Family Welfare ${ }^{6}$

\begin{tabular}{|c|c|}
\hline Category & Signs and symptoms \\
\hline Category A & $\begin{array}{l}\text { Patients with mild fever plus cough/sore throat } \\
\text { with or without body ache, headache, diarrhea and } \\
\text { vomiting }\end{array}$ \\
\hline \multirow[t]{7}{*}{ Category B } & $\begin{array}{l}\text { In addition to all the signs and symptoms } \\
\text { mentioned under category A }\end{array}$ \\
\hline & $\begin{array}{l}\text { - Patient has high grade fever and severe sore } \\
\text { throat }\end{array}$ \\
\hline & $\begin{array}{l}\text { - Individuals having one or more of the } \\
\text { following high-risk conditions }\end{array}$ \\
\hline & $\begin{array}{l}\text { Children with mild illness but with } \\
\text { predisposing risk factors }\end{array}$ \\
\hline & - Pregnant women \\
\hline & - Persons aged 65 years or older \\
\hline & $\begin{array}{l}\text { Patients with lung diseases, heart disease, } \\
\text { liver disease, kidney disease, blood } \\
\text { disorders, diabetes, neurological disorders, } \\
\text { cancer and HIV/AIDS and patients on long } \\
\text { term cortisone therapy }\end{array}$ \\
\hline \multirow[t]{4}{*}{ Category C } & $\begin{array}{l}\text { In addition to the above signs and symptoms of } \\
\text { categories } A \text { and } B \text {, if the patient has one or more } \\
\text { of the following: }\end{array}$ \\
\hline & $\begin{array}{l}\text { Breathlessness, chest pain, drowsiness, } \\
\text { fall in blood pressure, sputum mixed with } \\
\text { blood, bluish discoloration of nails }\end{array}$ \\
\hline & $\begin{array}{l}\text { - Children with influenza like illness who had a } \\
\text { severe disease as manifested by the red flag } \\
\text { signs (somnolence, high and persistent fever, } \\
\text { inability to feed well, convulsions, shortness } \\
\text { of breath, difficulty in breathing, etc.) }\end{array}$ \\
\hline & - Worsening of underlying chronic conditions \\
\hline
\end{tabular}

confirmed category $C$ cases during the period was assessed to analyse various variables that could affect the outcome of the disease including age, gender, co-relation with need for ventilation, relation with comorbidity, duration between onset of symptoms and hospitalization and length of stay. Data was analyzed using statistical measures like mean, percentage and Chi-square test.

\section{Results}

A total of 466 suspected patients reported to the emergency department of the hospital during the study period. Out of these, 137 patients (29.4\%) were found to be positive for swine flu virus infection. Table 3 shows year-over-year number of suspected and confirmed cases.

Out of the total number of 137 cases, $118(86.1 \%)$ patients were in category $C$. Table 4 illustrates year-over-year distribution of cases among categories $\mathrm{A}, \mathrm{B}$ and $\mathrm{C}$.

Table 5 shows that maximum number of category $C$ patients $(75.4 \%)$ are in age-group $21-60$ years $(p<0.001)$.

Table 6 shows the mortality was highest in 21-60 years of agegroup. Out of 89 patients in this age-group, 55 patients (61.8\%) could not survive. Statistically significant difference was observed for this age-group $(p<0.001)$.

There was no significant difference in occurrence ( $p=0.098)$ and mortality $(p=0.249)$ due to swine flu infection among males and females (Table 7).

Table 8 shows that a considerable number of patients in the age-group $21-40$ and $41-60$ years required mechanical ventilation and oxygen therapy.

Table 9 shows that out of 44 patients in the age-group of 21-60 years who were on mechanical ventilation, 43 patients (97.7\%) could not survive. Thus, death was significantly higher in this age-group $(p=0.001)$. Also, all the patients who were $>60$ years on mechanical ventilation lost their lives.

However, outcome was not related to age in the patients who were not on mechanical ventilation $(p=0.187)$ (Table 10)

Table 11 shows no significant association between comorbidity and outcome of the disease $(p=0.4122)$.

The duration between onset of symptoms and hospitalization ranged between 1-21 days; average was 4.7 days. The average length of stay of the swine flu confirmed cases was 6 days, ranging $1-36$ days.

Table 3: Year-wise suspected and confirmed swine flu cases

\begin{tabular}{lcc}
\hline Year (epidemic) & Suspected cases & $\begin{array}{l}\text { Confirmed } \\
\text { cases }\end{array}$ \\
\hline 2016 (epidemic 1) & 49 & $11(22.4 \%)$ \\
2017 (epidemic 2) & 169 & $56(33.1 \%)$ \\
2018 & 93 & $0(0 \%)$ \\
Till Feb, 2019 (epidemic 3) & 155 & $70(45.2 \%)$ \\
Total & 466 & $137(29.4 \%)$ \\
\hline
\end{tabular}

Table 4: Year-wise distribution of confirmed swine flu cases among different categories

\begin{tabular}{llll}
\hline & \multicolumn{3}{c}{ Category } \\
\cline { 2 - 4 } Year & $A$ & $B$ & $C$ \\
\hline Epidemic 1 & 0 & 1 & 10 \\
Epidemic 2 & 1 & 9 & 46 \\
Epidemic 3 & 1 & 7 & 62 \\
Total & $2(1.5 \%)$ & $17(12.4 \%)$ & $118(86.1 \%)$ \\
\hline
\end{tabular}


Hospital Administration for Swine Flu

Table 5: Age distribution of category $\mathrm{C}$ swine flu cases

\begin{tabular}{llccll}
\hline Age (years) & $\begin{array}{l}\text { Epidemic } 1 \\
(n=10)\end{array}$ & $\begin{array}{l}\text { Epidemic } 2 \\
(n=46)\end{array}$ & $\begin{array}{l}\text { Epidemic } 3 \\
(n=62)\end{array}$ & $\begin{array}{l}\text { Total } \\
(n=118)(\%)\end{array}$ & $\begin{array}{l}\text { Chi-square } \\
\text { test ( } p \text { value) }\end{array}$ \\
\hline$<20$ & 1 & 5 & 6 & $12(10.2)$ & $<0.001$ \\
$21-40$ & 5 & 17 & 23 & $45(38.1)$ & \\
$41-60$ & 2 & 17 & 25 & $44(37.3)$ & \\
$>60$ & 2 & 7 & 8 & $17(14.4)$ & \\
\hline
\end{tabular}

Table 6: Mortality among category $\mathrm{C}$ patients in different age groups

\begin{tabular}{lllccl}
\hline Age (years) & $\begin{array}{l}\text { Epidemic } 1 \\
(n=7)\end{array}$ & $\begin{array}{l}\text { Epidemic } 2 \\
(n=19)\end{array}$ & $\begin{array}{l}\text { Epidemic 3 } \\
(n=35)\end{array}$ & $\begin{array}{l}\text { Total } \\
(n=61)(\%)\end{array}$ & $\begin{array}{l}\text { Chi-square } \\
\text { test ( } p \text { value) }\end{array}$ \\
\hline$<20$ & 0 & 2 & 0 & $2(16.7)$ & $<0.001$ \\
$21-40$ & 4 & 5 & 18 & $27(60)$ & \\
$41-60$ & 2 & 12 & 14 & $28(63.6)$ & \\
$>60$ & 1 & 0 & 3 & $4(23.5)$ & \\
\hline
\end{tabular}

Table 7: Gender-wise occurrence and mortality among category C patients

\begin{tabular}{|c|c|c|c|c|c|c|c|c|c|c|c|}
\hline \multirow[b]{2}{*}{ Gender } & & \multicolumn{2}{|c|}{$\begin{array}{c}\text { Epidemic } 1 \\
(n=10)\end{array}$} & \multicolumn{2}{|c|}{$\begin{array}{c}\text { Epidemic } 2 \\
(n=46)\end{array}$} & \multicolumn{2}{|c|}{$\begin{array}{c}\text { Epidemic } 3 \\
(n=62)\end{array}$} & \multicolumn{2}{|c|}{$\begin{array}{c}\text { Total } \\
(n=118)\end{array}$} & \multicolumn{2}{|c|}{$\begin{array}{c}\text { Chi-square } \\
\text { test ( } p \text { value) }\end{array}$} \\
\hline & & $D^{*}$ & $D^{* *}$ & $D^{*}$ & $D^{* *}$ & $D^{*}$ & $D^{* *}$ & $D^{*}$ & $D^{* *}$ & $D^{*}$ & $D^{* *}$ \\
\hline \multirow[t]{2}{*}{ M } & No. & 4 & 3 & 22 & 9 & 24 & 14 & 50 & 26 & 0.098 & 0.249 \\
\hline & $\%$ & 40 & 75 & 47.8 & 41 & 38.7 & 58.3 & 42.4 & 52 & & \\
\hline \multirow[t]{2}{*}{$\mathrm{F}$} & No. & 6 & 4 & 24 & 10 & 38 & 21 & 68 & 35 & & \\
\hline & $\%$ & 60 & 66.7 & 52.2 & 41.7 & 61.3 & 55.3 & 57.6 & 51.5 & & \\
\hline
\end{tabular}

$M$, male; $D^{*}$, category $C$ patients

$\mathrm{F}$, female; $\mathrm{D}^{* *}$, mortality

Table 8: Effect of age on need for ventilatory support

\begin{tabular}{lcc}
\hline Age (years) & $\begin{array}{l}\text { Patients on mechanical } \\
\text { ventilation }(n=51)(\%)\end{array}$ & $\begin{array}{l}\text { Patients not on mechanical } \\
\text { ventilation (oxygen therapy) } \\
(n=67)(\%)\end{array}$ \\
\hline$<20$ & $4(7.9)$ & $8(11.9)$ \\
$21-40$ & $22(43.1)$ & $23(34.3)$ \\
$41-60$ & $22(43.1)$ & $22(32.8)$ \\
$>60$ & $3(5.9)$ & $14(21)$ \\
Chi-square test $(p$ value) & 0.083 & 0.093 \\
\hline
\end{tabular}

Table 9: Effect of age on mortality in patients on mechanical ventilation

\begin{tabular}{llll}
\hline Age (years) & $\begin{array}{l}\text { Discharge } \\
(n=3)(\%)\end{array}$ & $\begin{array}{l}\text { Death } \\
(n=48)(\%)\end{array}$ & $\begin{array}{l}\text { Chi-square test }(p \\
\text { value) }\end{array}$ \\
\hline$<20$ & $2(50)$ & $2(50)$ & 0.001 \\
$21-40$ & $1(4.5 \%)$ & $21(95.5)$ & \\
$41-60$ & 0 & $22(100)$ & \\
$>60$ & 0 & $3(100)$ & \\
\hline
\end{tabular}

Table 10: Effect of age on mortality in patients not on mechanical ventilation (oxygen therapy)

\begin{tabular}{llll}
\hline Age (years) & Discharge $(n=54)(\%)$ & Death $(n=13)(\%)$ & $\begin{array}{l}\text { Chi-square test } \\
(p \text { value })\end{array}$ \\
\hline$<20$ & $8(100)$ & 0 & 0.187 \\
$21-40$ & $17(73.9)$ & $6(26.1)$ & \\
$41-60$ & $16(72.7)$ & $6(27.3)$ & \\
$>60$ & $13(92.9)$ & $1(7.1)$ & \\
\hline
\end{tabular}


Table 11: Correlation between comorbidity and outcome of disease

\begin{tabular}{lllcl}
\hline Comorbidity & Death & Discharge & Total & $\begin{array}{l}\text { Chi-square } \\
\text { test ( } p \text { value) }\end{array}$ \\
\hline Yes & 27 & 21 & 48 & 0.4122 \\
No & 34 & 36 & 70 & \\
Total & 61 & 57 & 118 & \\
\hline
\end{tabular}

\section{Discussion}

In the present study, a total of 137 patients (29.4\%) were positive for swine flu infection out of 466 suspected patients who attended the emergency of the hospital from January, 2016 to February, 2019. The data show there has been a sudden increase in number of cases in year 2017 (epidemic 2) as compared to year 2016 (epidemic 1). Although no confirmed case of swine flu was reported in year 2018 in the hospital, 2019 (epidemic 3) has shown a sudden rise in number of swine flu patients. The data available from NCDC, New Delhi regarding prevalence of swine flu in India also shows sudden spurt of cases in year 2017 as compared to 2016. Although, the number of cases declined in 2018, the cases in year 2019 at the time of study were quite high. ${ }^{5}$ Absence of swine flu cases in year 2018 could create an illusion in the minds of hospital administrators in terms of the fact that disease has declined or disappeared from the society. But actually disease resurged in the year 2019, with higher number of cases than 2017. Thus, we recommend that the hospital administrators should avoid drawing conclusions from short-term data about the load of infective diseases like swine flu.

In the present study, 118 patients $(86.1 \%)$ of the total number of confirmed cases who reported to the hospital (137 patients) belonged to category C. Kashinkunti et al. and Kshatriya et al. also showed similar trends by demonstrating category $\mathrm{C}$ patients as $72.7 \%$ and $87.5 \%$ respectively. ${ }^{7,8}$

In our study, the most affected age group was 21-60 years with 89 patients (75.4\%) in this age-group and overall, mortality was also high in this age-group i.e., 55 patients (61.8\%) out of 89. In literature, however, the more severe cases and fatalities have been reported in the extremes of ages i.e., children younger than 5 years of age and elderly patients older than 65 years. ${ }^{9}$ But, there are other studies in literature which have shown findings similar to our study in terms of occurrence and mortality in different age-groups. ${ }^{10,11}$

Similarly, in terms of gender there is no consensus in literature. Our study shows no predisposition of either gender for swine flu while a study by Singh et al. and Dhawale et al. showed that females were affected more than males. ${ }^{10,12}$ Contrary to this, Kshatriya et al. reported more cases among males. ${ }^{8}$

The conflicting findings in literature in terms of age and gender may be due to the fact that there is no actual effect of age and gender in the occurrence, severity and mortality of the disease. Thus, to establish the fact that the age and gender does not affect the occurrence, severity and mortality of swine flu infection, every institute/center should record, preserve and report these data.

All the category $C$ patients needed airway support either in the form of mechanical ventilation $(43.2 \%, n=51)$ or oxygen therapy $(56.8 \%, n=67) 48(96 \%)$ out of 51 patients, who were put on mechanical ventilation, did not survive. The mortality was found to be highest (97.7\%) in 21-60 years of age-group. Thus, there is a need to analyze the cost effectiveness of putting patients on ventilator both for the patient and hospital. Moreover, the life becomes painful and cumbersome for the patients on ventilator and also there is risk of exposure to healthcare workers. So, there is a necessity to reassess which category of patients should be put on ventilator. A study by Anand demonstrated that 35\% patients required ventilatory support and the mean age of such patients was 30 years. Further, 74\% expired and majority were in age-group 21-39 years. ${ }^{13}$ Contrary to our study, the study conducted by Kashinkunti et al. showed $77.2 \%$ patients were put on mechanical ventilator and all survived. ${ }^{7}$ Hence, more research is required to identify the factors that can affect the outcome of patients on mechanical ventilation.

In our study with remaining 68 patients who were hypoxic and required oxygen therapy, 54 patients (80.6\%) were discharged in stable condition. Death of 13 patients (19.4\%) who were maintaining saturation with oxygen therapy was due to sudden cardiopulmonary arrest. The reason for the sudden arrest was either acute respiratory distress ( $84.6 \%$ cases) or aspiration after vomiting (15.4\%).

In the present study, total 48 patients (40.6\%) had associated comorbidities like diabetes (14.4\%), lung diseases like asthma, chronic lung disease and pulmonary tuberculosis (11\%), pregnancy (5.9\%), heart diseases like coronary artery disease, atrial septal defect and left ventricular failure (7.6\%) and kidney and neurological diseases (1.7\%). However, it was observed that comorbidity is neither associated with occurrence of disease nor with the mortality.

The mean duration between onset of symptoms and reporting to hospital was found to be 4.7 days, ranging between 1-21 days. A study by Kumar reported mean time to be $5.12 \pm 3.38$ days and by Jain as $5.80 \pm 2.81$ days. ${ }^{11,14}$ The interval from onset of symptoms to initiation of antiretroviral therapy correlates maximally with the severity of the disease. ${ }^{13}$ The severity of disease increases as antiretroviral treatment was not initiated within 48 hours of onset of symptoms.

The average length of stay was 6 days, ranging from 1-36 days. In contrast, Dhawale et al. in their study reported that the mean duration of stay was $1.880 \pm 1.2$ days. ${ }^{12}$

Our study has some limitations, like small sample size as it was a single center inpatient based study and secondly, disease is seasonal/epidemic.

\section{Conclusion}

Epidemic of swine flu is a menace as it claims the lives of many every year. Proper planning by hospital administrators in terms of infrastructure, availability and accessibility of resources, sufficient manpower for managing the epidemic can reduce the mortality rate. Further, this can only be done based on understanding of the variable trend of disease and various factors affecting the outcome of disease.

\section{Clinical Significance}

The study will help the hospital administrators to understand the variable trend of disease and demographic profile planning for management of swine flu epidemic.

\section{References}

1. Dandagi GL, Byahatti SM. An insight into the swine-influenza $A$ (H1N1) virus infection in humans. Lung India 2011;28(1):34-38. DOI: 10.4103/0970-2113.76299.

2. Rajesh M, Kishore $D$, Ramesh $B$. A review on study of swine flu. Indo Glob J Pharm 2011;1:47-51.

3. Neumann G, Noda T, Kawaoka Y, et al. Emergence and pandemic potential of swine-origin H1N1 influenza virus. Nature 2009 Jun 18;459(7249):931-939. DOI: 10.1038/nature08157. 
4. Cutler J, Schleihauf E, Hatchette TF, et al. Investigation of the first cases of human-to-human infection with the new swine-origin influenza A (H1N1) virus in Canada. Cmaj 2009 Aug 4;181(3-4):159-163. DOI: 10.1503/cmaj.090859.

5. Seasonal Influenza (H1N1) - State/UT- wise, Year- wise number of cases and death from 2012 to 2019 (till 24th February, 2019). https:// www.flutrackers.com/forum/forum/india/seasonal-flu-2009-2014including-h1n1-pandemic-2009-ai/805429-india-influenza-2019-1083-fatalities. Accessed on February 26, 2019.

6. Guidelines on Categorization of Influenza A H1N1 Cases during Screening for Home Isolation, Testing Treatment, and Hospitalization (Revised on 18.10.2016). https://www.mohfw.gov.in/sites/default/ files/394697031477913837_3.pdf. Accessed on February 28, 2019.

7. Kashinkunti MD, Gundikeri SK, Dhananjaya M, et al. Study of clinical profile of patients with H1N1 influenza in a teaching hospital of North Karnataka. IJRRMS 2013;3:53-55.

8. Kshatriya RM, Khara NV, Ganjiwale J, et al. Lessons learnt from the Indian H1N1 (swine flu) epidemic: Predictors of outcome based on epidemiological and clinical profile. J Family Med Prim Care 2018 Nov;7(6):1506-1509. DOI: 10.4103/jfmpc.jfmpc_38_18.
9. Jilani TN, Jamil RT, Siddiqui AH. H1N1 Influenza (Swine Flu); 2019. https://www.ncbi.nlm.nih.gov/books/NBK513241/. Accessed on March 20, 2019.

10. Singh M, Sharma S. An epidemiological study of recent outbreak of influenza A H1N1 (Swine Flu) in Western Rajasthan region of India. J Med Allied Sci 2013 Aug 31;3(2):48.

11. Kumar S. A Study of Outbreak of Swine Flu (H1N1) in North-West Zone of Rajasthan (Current Status-2015). J Assoc Physicians India 2016 Jul;64(7):46-49.

12. Dhawale $\mathrm{S}$, Jayant $\mathrm{S}$. Clinical profile, morbidity and mortality among swine flu (H1N1) infected patients: 2015 Gwalior, Madhya Pradesh pandemic, India. Int J Adv Med 2016;3(2):324-327. DOI: 10.18203/2349-3933.ijam20161084.

13. Anand R, Gupta A, Gupta A, et al. Management of swine-flu patients in the intensive care unit: Our experience. J Anaesthesio Clin Pharmacol 2012 Jan;28(1):51-55. DOI: 10.4103/0970-9185. 92436.

14. Jain A, Sharma R, Nagar MK, et al. A Death Audit of H1N1 Influenza Cases in a Tertiary Care Hospital in Southern Rajasthan (Current Out Break-2017). Natl J 2018;9(5):380-384 